\title{
SURFACE CHARACTERIZATION OF PLATINUM STIMULATING ELECTRODES USING AN ELECTROCHEMICAL SCANNING METHOD
}

\author{
KARAKTERIZACIJA POVRŠINE PLATINASTIH STIMULACIJSKIH \\ ELEKTROD S POMOČJO ELEKTROKEMIJSKE VRSTIČNE \\ METODE
}

\author{
Andraž Mehle1, Janez Rozman ${ }^{2,3}$, Martin Šala ${ }^{4}$, Samo Ribarič ${ }^{3}$, Polona Pečlin² \\ ${ }^{1}$ Sensum d. o. o., Tehnološki park 21, 1000 Ljubljana, Slovenia \\ ${ }^{2}$ Centre for Implantable Technology and Sensors, ITIS d. o. o. Ljubljana, Lepi pot 11, 1000 Ljubljana, Slovenia \\ 3Institute of Pathophysiology, Medical Faculty, University of Ljubljana, Zaloška 4, 1000 Ljubljana, Slovenia \\ ${ }^{4}$ Analytical Chemistry Laboratory (L04), National Institute of Chemistry, Hajdrihova 19, Ljubljana, Slovenia \\ janez.rozman@guest.arnes.si
}

Prejem rokopisa - received: 2017-04-25; sprejem za objavo - accepted for publication: 2017-06-28

doi:10.17222/mit.2017.044

\begin{abstract}
The purpose of this article is to investigate the electrochemical performance of platinum stimulating nerve electrodes (WE1 and WE2) with different surface structures to define which one is able to produce a higher neural activation function during nerve stimulation than that achieved by conventional electrodes. The purpose is also to present a method that enables the electrochemical scanning of stimulating electrode surfaces. The surface of WE1 was modified using rough sand paper, while the surface of WE2 was modified using fine sand paper. The potential at the different roughened surfaces in the sodium phosphate mixture, when excited with specific current pulses, was measured against a $\mathrm{Ag} / \mathrm{AgCl}$ reference electrode. Voltage transients were recorded to determine the polarization across the electrode-electrolyte interface. The results indicate that the surface of WE1 could deliver more current to the nerve tissue and more activation for a fixed input voltage than WE2. Namely, it is shown that the mean $\left|Z_{\text {pol }}\right|$ of WE1 was lower than that for WE2 $(237.1 \Omega$ vs. $251 \Omega)$. Accordingly, the platinum electrode that was superficially modified using rough sand paper is more suitable for safe and efficient nerve stimulation than the electrode that was superficially modified using fine sand paper.

Keywords: platinum, polarization, interfaces, potential parameters
\end{abstract}

Namen članka je preiskati elektrokemijske lastnosti platinastih elektrod WE1 in WE2 za stimulacijo živca, ki imata različni površinski strukturi, s ciljem določiti katera od njiju je sposobna povzročiti večjo aktivacijsko funkcijo vlaken med stimulacijo glede na konvencionalno površino. Namen je tudi predstaviti metodo, ki omogoča elektrokemijsko vrstično preiskavo površin stimulacijskih elektrod. Površina WE1 je bila obdelana z grobim brusnim papirjem medtem, ko je bila površina WE2 obdelana s finim brusnim papirjem. Potencial različno grobih površin v fiziološki raztopini pri vzdraženju s specifičnimi stimulacijskimi impulzi je bil merjen glede na $\mathrm{Ag} / \mathrm{AgCl}$ referenčno elektrodo. Napetostni prehodni pojavi so bili zajeti z namenom določitve polarizacije na prehodu med elektrodo in elektrolitom. Rezultati kažejo, da lahko WE1 dovede na živec več toka in s tem doseže večjo aktivacijo pri konstantni napetosti kot WE2. Izkazuje se namreč, da je polarizacijska upornost $\left|Z_{\text {pol }}\right|$ pri WE1 manjša kot pri WE2 $(237.1 \Omega$ proti $251 \Omega$ ). Potemtakem je elektroda, ki je bila brušena z grobim brusnim papirjem, bolj primerna za varno in učinkovito stimulacijo živca, kot elektroda, ki je bila brušena s finim brusnim papirjem.

Ključne besede: platina, polarizacija, prehodi, parametri potenciala

\section{INTRODUCTION}

In recent decades, considerable scientific and technological efforts have been devoted to understanding and characterizing the interface between a stimulating electrode and its surrounding medium. In this region, a transduction of charge carriers occurs from electrons in the metal electrode to ions in the tissue, which is exceptionally important in determining how the electrodes respond to charge injection. To be specific, characterizing the electrode-tissue interface is crucial to determining safe charge delivery to the nerve. ${ }^{1-3}$

In implantable prosthetic devices, electrodes are the interfaces between the electronic circuitry and nerve tissue and can be used for neural stimulation and/or neural signal recording. In the past few years, implanted electrodes have been used extensively for efficient stimulation of peripheral nervous systems. Although much effort has been made to find optimal anatomical targets for different nerve-stimulation techniques, little work has been done to improve the efficiency of nerve stimulation using analytically driven designs and configurations of the stimulating electrodes.

The electrode geometry itself plays a significant role in controlling the activation of neuron populations. ${ }^{4}$ In this connection, the electrode geometry can affect the impedance, spatial distribution of the electric field in the tissue, and consequently the pattern of neural excitation. One approach to enhance the efficiency of neural stimulation is to increase the irregularity of the surface current profile, which can be quantified by defining a metric known as the topological edginess. ${ }^{5}$ 
In this relation, adequately optimized electrode geometries and surfaces that increase the variation of the current density on the electrode surface also increase the efficiency of the neural stimulation. ${ }^{5,6}$ This is in accordance with the suppositions of E. N. Warman et al. ${ }^{7}$ and F. Rattay ${ }^{8}$; they showed that electrode-induced neural excitation could be predicted using the driving function of a neuron, which is directly proportional to the second spatial derivative of the extracellular potential and thus, the spatial derivative of the current density in the tissue. Therefore, electrode geometries with a greater roughness and more sharp edges can increase the stimulation efficiency by increasing the spatial derivative of the current density, and therefore the driving function.

However, specific neural stimulation applications sometimes require high electrode charge densities that may lead to high energy transfer and elicit chemical reactions that involve changes in the electrode properties and even corrosion. In this relation, A. Hung et al. ${ }^{9}$ described a pulse-clamp technique that could be used to accurately quantify the roughness modification in an electrode used in selective nerve stimulation applications that demand both a large amount of charge injection and a small electrode size. However, to ensure safe and reversible charge injection for stimulation, all applications require low-impedance electrodes. In this relation, the medium surrounding the stimulating electrodes is exceptionally important to determine how they respond to charge injection. Consequently, for the development of chronically implanted multi-electrode devices, an understanding of the electrochemical mechanisms underlying the behavior of neural stimulation electrodes is important.

When platinum is used as the material for stimulating electrodes, it injects charge by both reversible Faradaic reactions and double-layer (DL) charging. However, reversible Faradaic reactions predominate under most stimulating conditions. ${ }^{10-12}$ Furthermore, changes in the electrolyte composition adjacent to the electrode and the finite rate of Faradaic reactions can lead to irreversible processes that cause electrode degradation or tissue injury. ${ }^{13-16}$

In most in-vitro experiments, the electrodes were submerged in a certain electrolyte to simulate a specific physiological medium. ${ }^{17,18}$ For in-vitro experiments, voltage transient (VT) measurements are used to estimate the charge-injection limit, which defines the quantity of charge that can be injected in a current-controlled stimulation pulse by electrochemical reversible processes only. More precisely, VTs are analyzed to determine the maximum negative polarization $\left(E_{\mathrm{mc}}\right)$ and maximum positive polarization $\left(E_{\mathrm{ma}}\right)$ across the electrode-electrolyte interface. These potential extremes are then compared to the established maximum potentials, beyond which it is considered unsafe to polarize the electrode (typically the water electrolysis potential window). ${ }^{19,20}$
Determining the optimum surface roughness for stimulating electrodes is a challenging topic. In recent years, a variety of mechanical adaptations, such as adaptations to the geometry and surface roughness of the electrodes, to contribute to neuro-prostheses designs have been investigated and implemented..$^{5,6}$ Namely, the geometry of an electrode significantly affects the shape of the generated electric field, which in turn affects the current density produced by the electrode.

The efficiency of a stimulating electrode is characterized by its ability to activate a certain volume of neural tissue with lower voltage and power requirements. ${ }^{5,6}$ Electrode designs involving a greater amount of sharp peaks and edges will have higher current density variations than electrodes with flat or rounded edges (the higher current density variations will increase the stimulation efficiency). Besides, such an electrode activates a significantly larger number of axons with a lower threshold than electrodes with smooth or rounded edges. ${ }^{21}$ In this regard, L. Golestanirad et al. ${ }^{5}$ demonstrated that the feasibility of increasing the stimulation efficiency using modified fractal geometries is still beyond the levels already reported in the literature. Related experimental studies have shown that neural stimulation can be improved by creating a rougher surface; however, the electrodes are covered with a layer of material with a high porosity. ${ }^{6,21}$ Nevertheless, the electrode functionality can also be increased by depositing conducting porous polymers with incorporated cell adhesion peptides, proteins, and anti-inflammatory drugs. ${ }^{22,23}$ Most of these improvements could reduce the fibrous tissue encapsulation thickness because of tissue in-growth. However, smooth surfaces would make it more difficult to initiate corrosion.

There is a need to accurately predict the neural activation as a function of the stimulation parameters and electrode design; thus, we evaluate the effects of the electrode surface conditions on the electrochemical performance of the platinum electrode for selective nerve stimulation in vitro.

For this purpose, a method for the in-vitro evaluation of platinum electrodes for use in neural stimulation applications, was developed. The present work focuses on modifying the geometry of the rectangular platinum electrode to produce a higher neural activation function than that achieved by conventional electrodes. ${ }^{8}$ In this relation, the aim is to increase the surface current irregularity while maintaining the amount of total current delivered to the tissue. We present the preliminary results for these electrodes with mechanically modified surfaces. Our hypothesis is that such a modified surface could increase the irregularity of the current density profile on the electrode surface, and consequently in the adjacent nerve tissue. For this purpose, a method that enables an in-vitro assessment of the electrochemical performance of stimulating electrodes using modified electrode geo- 
metries was developed. ${ }^{24,25}$ This article investigates the electrochemical performance of two stimulating electrodes with different surface structures obtained by treating the surface with smooth and rough sand paper.

\section{EXPERIMENTAL PART}

\subsection{Electrochemical cell}

The body of the electrochemical cell (Figure 1) was machined from bulk polyamide (nylon) using a milling machine. The dimensions and design of the cell were optimized to enable easy manipulation of the electrical connections and three electrodes. For the measurements, a 0.03-mm-thick silicone strip embedding tested electrodes (working electrode number one (WE1) and working electrode number two (WE2)), was adhered onto the top of the cylinder made of polyamide (Novilon) using the medical-grade silicone adhesive. Then, the cylinder was mounted at the bottom of the chamber using a medical-grade silicone adhesive (Med RTV Adhesive, Implant Grade 40064, Applied Silicone Corporation).

In the developed technique, only the working electrode (WE) uncovered face was investigated, while the other surfaces were insulated from the electrolyte. The auxiliary electrode (AE) with a large geometrical area $\left(\sim 600 \mathrm{~mm}^{2}\right)$ was created by adhering a platinum ribbon to the inner walls of the cell (approximately $20 \mathrm{~mm}$ from the WEs and the reference electrode (RE)). The RE was a simple open-ended standard $\mathrm{Ag} / \mathrm{AgCl}$ glass $\mathrm{RE}$, REF-10 (UNISENSE A/S, Denmark) with an outside tip diameter of $10 \mu \mathrm{m}$.

For our measurements, the WE is large enough and the standard glass RE small enough that the surface of the investigated stimulating electrode could be divided into the number of locations where measurements could be performed.

The voltage drop between the RE and WE (actually arising from the series resistance, including the solution resistance between the WE and the RE plus the electrical

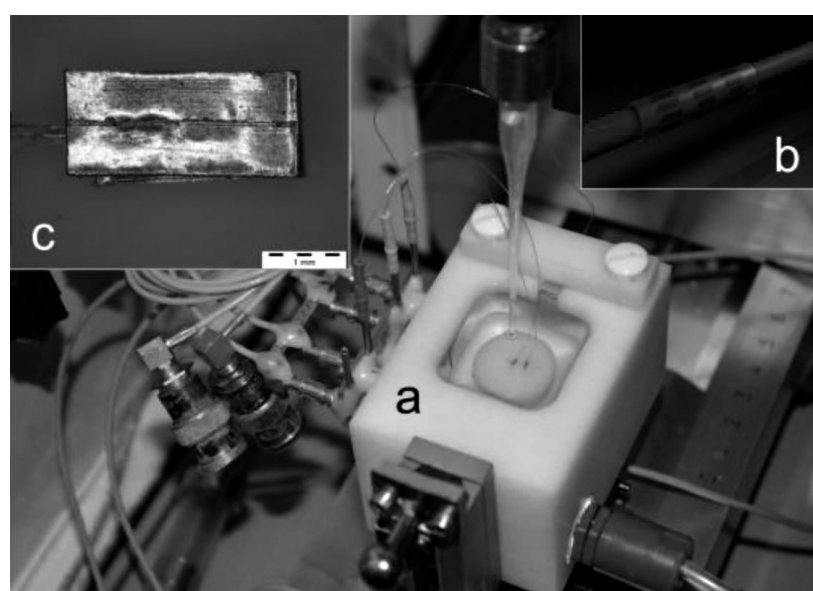

Figure 1: a) Electrochemical cell, b) perspective 3D illustration of the stimulating spiral nerve cuff and c) working electrode resistance of the lead wire) was minimized by positioning the RE approximately $0.05 \mathrm{~mm}$ from the WE. For this purpose, a 3D micro-manipulator was installed on the chamber.

Prior to experimentation, the WE surface was cleaned by rubbing in a letter-I pattern for a period of $30 \mathrm{~s}$ using a polishing cotton tip. Afterwards, the WE surface was rinsed thoroughly with ethanol, then de-ionized with distilled water and air-dried. Finally, the chamber was filled with a phosphate-buffered saline (PBS) solution, as summarized in Table $\mathbf{1}$.

Table 1: PBS solution composition

\begin{tabular}{|c|c|c|c|}
\hline Component & $\begin{array}{c}\text { Mass } \\
\text { concentration } \\
(\mathrm{g} / \mathrm{L})\end{array}$ & $\begin{array}{c}\text { Molar } \\
\text { concentration } \\
(\mathrm{mM})\end{array}$ & $\begin{array}{c}\text { Molar mass } \\
(\mathrm{g} / \mathrm{mol})\end{array}$ \\
\hline & 7.36 & 126 & 58.4425 \\
\hline $\mathrm{NaCl}$ & 11.5 & 81 & 141.959 \\
\hline $\mathrm{Na}_{2} \mathrm{HPO}$ & 3.04 & 22 & 137.992 \\
\hline $\mathrm{NaH}_{2} \mathrm{PO} 4 \cdot \mathrm{H}_{2} \mathrm{O}$ & $\mathrm{pH}=7.27, \mathrm{~T}=21.4^{\circ} \mathrm{C}$ \\
\hline \multicolumn{3}{|c|}{} \\
\hline
\end{tabular}

The measured VT was amplified using one channel of the high-performance differential amplifier (Teledyne LeCroy DA1855A-PR2). However, the voltage drop across the precision serial resistor at the stimulator output (10 $\Omega$ ) was measured using a custom-designed differential amplifier with the gain $(A)$ set at $A=10$. A dual-channel digital oscilloscope (TekScope, Tektronix) was used to monitor both the VT and the drop across the precision serial resistor. The VT measurements between one of the WEs and the AE were performed at room temperature in the PBS solutions (schematically shown in Figure 2). The data was collected at $200 \mathrm{kHz}$ using a USB 2.0 interface with a high-performance data-acquisition system (DEWE-43, Dewesoft, Slovenia) and Dewesoft 7.0.2 acquisition software developed by the

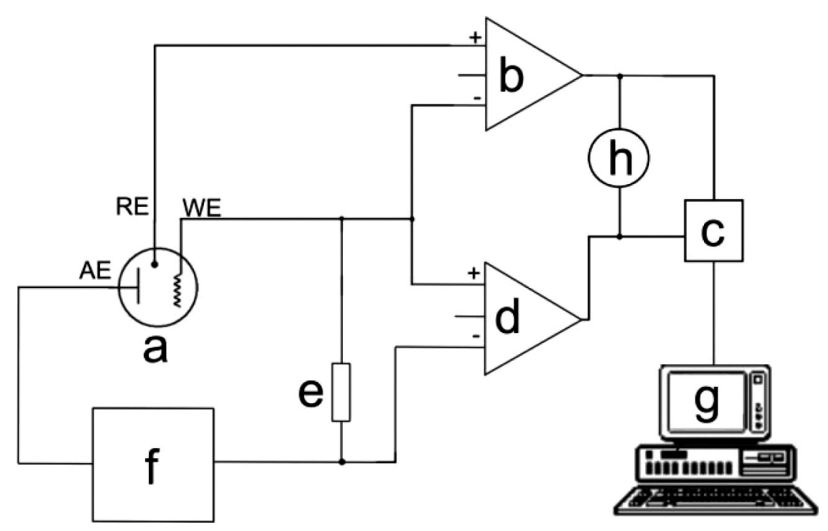

Figure 2: Schematic diagram of the measuring setup comprising the following units: a) electrochemical cell, reference electrode (RE), working electrode (WE), and auxiliary electrode (AE), b) differential amplifier, c) data-acquisition system, d) differential amplifier, e) precision serial resistor (RM), f) precision custom-designed stimulator, g) $\mathrm{PC}$ and $\mathrm{h}$ ) oscilloscope 
same company and stored on a portable computer (LenovoT420, China).

\subsection{Crafting the working electrodes}

Crafting the WEs involved several steps: 1) cutting 0.66 -mm-wide strips from the 0.03 -mm-thick platinum foil using a sharp blade, 2) cutting two 6-mm-long individual strips, 3) folding the obtained strips into thirds, creating U-shaped forms, and 4) inserting the 2-mmwide strip made of the silicone sheet between the U-shaped structure to form a sandwich structure. The final dimensions of the electrode surfaces exposed to the PBS were width $=0.66 \mathrm{~mm}$, length $=3 \mathrm{~mm}$, and surface area $=2 \mathrm{~mm}^{2}$.

The interconnection between the WEs and the lead wires was performed using a simple construction custom-designed micro-spot-welder based on a thyristor and powered using a large capacitor discharge by highly experienced and well-trained personnel. An energy of approximately $6 \mathrm{Ws}$ (defined experimentally) provided reproducible results for the proposed application of welding the lead wire (AS 631, Cooner Wire, USA) within the sandwich structure. The welding energy for both electrodes is defined in Table 2 . This table also provides information for the two different types of sand paper (Waterproof Silica Carbide Paper FEPA P\#500 and FEPA P\#4000, Struers ApS, Denmark) that were used to increase the real surface of the WEs. Specifically, the surface of WE1 was enlarged using rough sand paper (FEPA P\#500) while WE2 was enlarged using finegrained sand paper (FEPA P\#4000). In this relation, each of the WE surfaces was treated by grinding in a letter-I pattern for a period of $10 \mathrm{~s}$ using an appointed sand paper and vertical force of approximately $5 \mathrm{~N}$.

In Figure 1, WE1 is situated at the right-hand side of the cell and WE2 at the left-hand side of the cell.

Table 2: Welding energy and sand paper used in the experiments

\begin{tabular}{|c|c|c|c|c|}
\hline WE & $\begin{array}{c}\text { Charging } \\
\text { current }(\mathrm{A})\end{array}$ & $\begin{array}{c}\text { Charging } \\
\text { voltage (V) }\end{array}$ & $\begin{array}{c}\text { Welding } \\
\text { energy (Ws) }\end{array}$ & Sand paper \\
\hline 1 & 5 & 2 & 6 & FEPA P\#500 \\
\hline 2 & 5 & 2 & 6 & $\begin{array}{c}\text { FEPA } \\
\text { P\#4000 }\end{array}$ \\
\hline
\end{tabular}

\subsection{VT measurements}

VTs were measured using a biphasic, quasi-trapezoidal current stimulating pulse waveform (pulse) with the intensity of the cathodic phase $\left(i_{\mathrm{c}}\right)$, which was previously tested in selective nerve stimulation on an isolated left porcine vagus nerve (not shown in this paper) ${ }^{26}$, delivered from the precision custom-designed stimulator between an appointed WE and the AE. The relevant parameters $\left(i_{\mathrm{c}}=-4.0 \mathrm{~mA}\right.$; width of the cathodic phase, $t_{\mathrm{c}}=155 \mu \mathrm{s}$; width of the cathodic exponential decay, $t_{\exp }=100 \mu \mathrm{s}$; time constant of the exponential decay, $\tau_{\text {exp }}=45 \mu \mathrm{s}$; intensity of the anodic phase, $i_{\mathrm{a}}=0.45 \mathrm{~mA}$; width of the anodic phase, $t_{\mathrm{a}}=490 \mu \mathrm{s}$; charge density within the cathodic phase, $\sigma_{\mathrm{qc}}=-800.00 \mu \mathrm{C} / \mathrm{cm}^{2}$; and charge density within the anodic phase, $\sigma_{\mathrm{qa}}=849.00$ $\mu \mathrm{C} / \mathrm{cm}^{2}$ ) were pre-set by the stimulator. For this pulse, $E_{\mathrm{mc}}$ and $E_{\mathrm{ma}}$ were measured across the electrode-electrolyte interface. These potentials were then tested to determine whether any of them exceeded the values confining the water electrolysis window, which were defined using cyclic voltammetry (not shown in this paper; $[-0.60 \mathrm{~V}+0.85 \mathrm{~V}]$ measured in PBS $).{ }^{27-29}$

There were several characteristic voltages and potentials that contributed to the entire voltage drop $(\mathrm{d} V)$ and were accounted for in the calculations of $E_{\mathrm{mc}}$ and $E_{\text {ma }}$ : polarization across the electrode-electrolyte interface $\left(\mathrm{d} E_{\mathrm{p}}\right)$, potential of the WE at the onset of the pulse $\left(E_{\text {ipp }}\right)$, and access voltage ( $V_{\mathrm{a}}$; drop across the electrolyte resistance plus over-potential terms). $E_{\mathrm{mc}}$ is defined by Equation (1): ${ }^{30}$

$$
E_{\mathrm{mc}}=E_{\text {ipp }}+\mathrm{d} E_{\mathrm{p}}=E_{\text {ipp }}+\left(\mathrm{d} V-V_{\mathrm{a}}\right)
$$

VTs above each of the two WEs were measured from various locations on the surface of the WE while the above-mentioned pulses were applied between the WE and CE. The scanning displacements, transverse according to each of the two WEs, were controlled optically using a precise micrometre dial, while at the same time, they were measured using precise linear potentiometer $(20 \mathrm{k} \Omega$ ) connected to the aforementioned high-performance data-acquisition system. During the scanning, the tip of the RE was situated as close as possible to the WEs using a micrometre enabling precise vertical displacement.

\subsection{VT analysis}

A set of approximately 160 VTs, each corresponding to a specific location at the investigated WE obtained by the displacement $\Delta x$ performed by the RE above the WE was measured. Afterwards, each VT in a set was automatically analysed/processed to determine the aforementioned characteristic voltages and potentials that contributed to the entire voltage drop dV. Characteristic voltages and potentials for a certain set (displacement $\Delta x$ ) were then calculated as the mean of all the values in a set. In this regard, the potential of the WE at the onset of the pulse $E_{\mathrm{pp}}$ was estimated as the mean value of 50 measured signal samples before the onset of the pulse. The points that determine the voltage $V_{\mathrm{a}}$ and the potential $E_{\text {ma }}$ of the VT are located at pulse times where the rate of change of inclination of the signal tangent is high. Thus, the times $t_{V_{\mathrm{a}}}$ and $t_{\mathrm{E}_{\text {ma }}}$ of those points were estimated by locating local maxima of the second derivative of the voltage response. The second derivative of the signals was estimated by convolving the signals with a digital filter of the form [ $\left[\begin{array}{lll}-1 & 0 & 1\end{array}\right]$ twice. The voltage $V_{\mathrm{a}}$ and the potential $E_{\mathrm{ma}}$ for voltage transient $V(t)$ are defined as shown in Equations (1) and (3): 
A. MEHLE et al.: SURFACE CHARACTERIZATION OF PLATINUM STIMULATING ELECTRODES ..

$$
\begin{gathered}
V_{\mathrm{a}}=\left|E_{\mathrm{ipp}}-V\left(t_{V_{\mathrm{a}}}\right)\right| \\
E_{\mathrm{ma}}=V\left(t_{E_{\mathrm{ma}}}\right)
\end{gathered}
$$

Once we have the estimations for $V_{\mathrm{a}}$ and $E_{\mathrm{ma}}$, the calculation of all the other voltage and potentials shown in Equations (4), (5) and (6), is straightforward:

$$
\begin{gathered}
\Delta V=\left|E_{\mathrm{ipp}}-\min _{\mathrm{t}} V(t)\right| \\
\Delta E_{\mathrm{p}}=\Delta V-V_{\mathrm{a}} \\
E_{\mathrm{mc}}=\min _{\mathrm{t}} V(t)+V_{\mathrm{a}}
\end{gathered}
$$

Afterwards, the polarization impedance $|\mathrm{Zpol}|$ was calculated as $\mathrm{d} E_{\mathrm{p}} /$ ic at location $x$, where the RE was the closest to the WEs, i.e., at the middle of the electrodes.

\section{RESULTS AND DISCUSSION}

Figure 3 shows the stimulation pulse and elicited VT with the indicated characteristic voltage and potential elements that contributed to $\mathrm{dV}$, i.e., $E_{\mathrm{ipp}}, V_{\mathrm{a}}$, and $\mathrm{d} E_{\mathrm{p}}$ in both WEs. These elements were then accounted for in the calculation of $E_{\mathrm{mc}}$ and $E_{\mathrm{ma}}$ in each of the two WEs.

Figure 3 shows that the onset of $i_{\mathrm{c}}$ elicited the near-instantaneous VT voltage, where $\mathrm{V}_{\mathrm{a}}$ could be easily determined at the instant rise. However, when $i_{\mathrm{c}}$ was terminated, the behavior of the potential in the exponential decay region where $i_{\mathrm{c}}$ was exponentially approaching the lowest value prevented an easy determination of $V_{\mathrm{a}}$. In this regard, the analysis technique described by $\operatorname{Cogan}^{30}$, which introduced a short interruption of the stimulation current between the cathodic and anodic phase of the pulse, could not be used because of the quasi-trapezoidal stimulation waveform used in the study.

$E_{\mathrm{mc}}$ and $E_{\mathrm{ma}}$, scanned over WE1 and WE2, are demonstrated in Figure 4. The figure also shows the values for $E_{\mathrm{ipp}}, \mathrm{d} V, V_{\mathrm{a}}$, and $\mathrm{d} E_{\mathrm{p}}$.

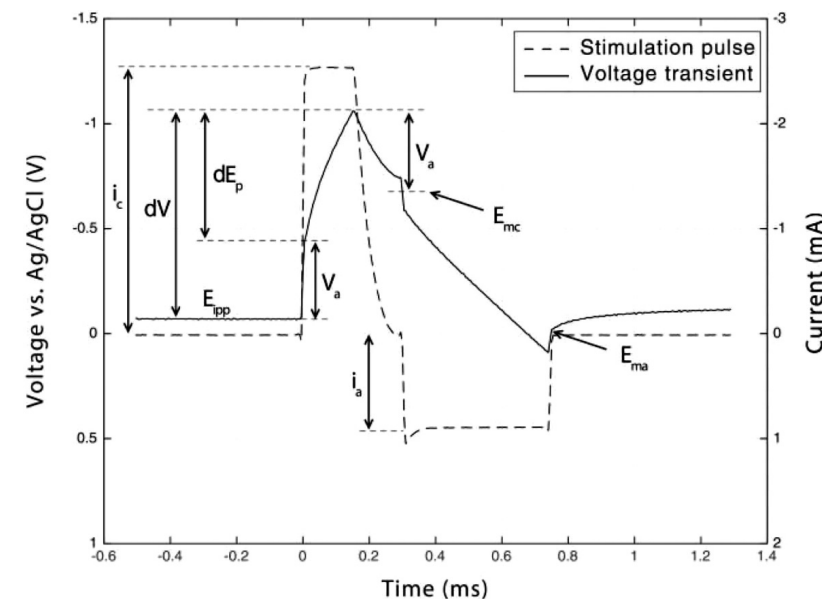

Figure 3: Stimulation pulse and elicited VT in WEs with the indicated elements that contributed to the entire voltage drop, $\mathrm{d} V$

\subsection{Results for WE1}

Figure 4 shows that the average $\mathrm{d} E_{\mathrm{p}}$ in WE1 is 0.59 $\mathrm{V}$. The value of $V_{\mathrm{a}}$ is $0.24 \mathrm{~V}$, while the value of $E_{\text {ipp }}$ is $-0.11 \mathrm{~V}$. It is difficult to accurately measure $\mathrm{V}_{\mathrm{a}}$ when $\mathrm{i}_{\mathrm{c}}$ is terminated, which is a practical issue when determining $E_{\mathrm{mc}}$, as shown in Figure 3. However, $E_{\mathrm{ma}}$ was determined with relative ease. As in the VT of the pulse used, $E_{\mathrm{mc}}$ and $E_{\mathrm{ma}}$ reached values of $-0.7 \mathrm{~V}$ and $-0.01 \mathrm{~V}$, respectively. Accordingly, $E_{\mathrm{mc}}$ slightly exceeded the safe potential limits for water electrolysis, while $E_{\mathrm{ma}}$ remained slightly negative and did not exceed this limit. Figure 4 also shows that WE1 was cathodically limited for the pulse waveform used; i.e., $E_{\mathrm{mc}}$ reached the cathodic limit before $E_{\mathrm{ma}}$ reached the anodic limit of the water electrolysis window. $\mathrm{d} V$ was $0.83 \mathrm{~V}$ across the electrode-electrolyte interface.

\subsection{Results for WE2}

Figure 4 shows that the average $\mathrm{d} E_{\mathrm{p}}$ in WE2 was $0.615 \mathrm{~V}$; the value of $V_{\mathrm{a}}$ was $0.109 \mathrm{~V}$, and the value of $E_{\text {ipp }}$ is $-0.075 \mathrm{~V}$. Again, the practical issue in determining

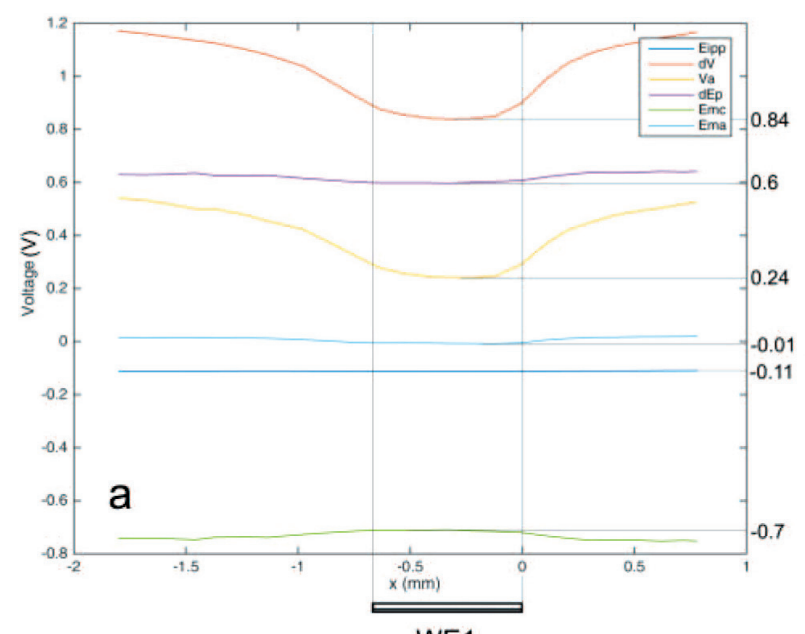

WE1

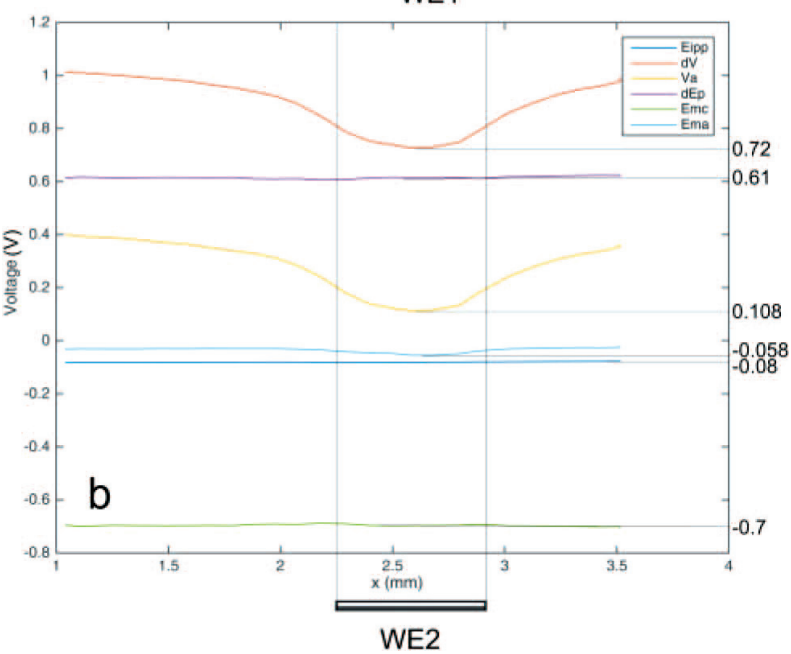

Figure 4: Schematic side-view diagram of the WEs and variables, $E_{\mathrm{ipp}}, \mathrm{d} V, V_{\mathrm{a}}, \mathrm{d} E_{\mathrm{p}}, E_{\mathrm{mc}}$, and $E_{\mathrm{ma}}:$ a) WE1 and b) WE2 
$E_{\mathrm{mc}}($ Figure 3) is the difficulty in accurately measuring $V_{\mathrm{a}}$ when $\mathrm{i}_{\mathrm{c}}$ is terminated. $E_{\mathrm{mc}}$ and $E_{\mathrm{ma}}$ reached values of $-0.7 \mathrm{~V}$ and $-0.054 \mathrm{~V}$, respectively as for the $\mathrm{VT}$ of the pulse. Accordingly, $E_{\mathrm{mc}}$ slightly exceeded the safe potential limits for water electrolysis, while $E_{\mathrm{ma}}$ (determined with relative ease) remained slightly negative and did not exceed this limit. Figure $\mathbf{4}$ also shows that WE2 was cathodically limited at the pulse waveform that was used; i.e., $E_{\mathrm{mc}}$ reached the cathodic limit before $E_{\mathrm{ma}}$ reached the anodic limit of the water electrolysis window. $\mathrm{d} V$ was $0.72 \mathrm{~V}$ across the electrode-electrolyte interface.

Figure 5 shows the voltage changes of the variables $\mathrm{d} E_{\mathrm{p}}, E_{\mathrm{mc}}$, and $E_{\mathrm{ma}}$ as scanned over WE1 and WE2. The average variability in $E_{\mathrm{mc}}$ and $E_{\mathrm{ma}}$ were assumed to increase as the number of sharp peaks and edges produced on the surface of WE1 increased. ${ }^{31}$ These results support the hypothesis, i.e., that the current density would decrease with a greater number of sharp peaks and edges on WE1. Finally, Table 3 shows $\left|Z_{\text {pol }}\right|$ calculated from $\mathrm{d} E_{\mathrm{p}} /$ ic at $x$, where the RE was the closest to the WEs, i.e., at the middle of electrodes.

Table 3: Polarization impedance $\left|Z_{\text {pol }}\right|$ for WE1 and WE2 derived from two scans

\begin{tabular}{|c|c|c|c|c|c|c|}
\hline \multicolumn{2}{|c|}{} & \multicolumn{5}{|c|}{$\mathrm{d} E \mathrm{p}(\mathrm{V})$} \\
\cline { 3 - 7 } \multicolumn{2}{|c|}{} & \multicolumn{3}{|c|}{ WE1 } & \multicolumn{2}{c|}{ WE2 } \\
\cline { 2 - 7 } & $\begin{array}{c}\text { First } \\
\text { scan }\end{array}$ & $\begin{array}{c}\text { Second } \\
\text { scan }\end{array}$ & $\begin{array}{c}\text { Mean } \\
\text { value }\end{array}$ & $\begin{array}{c}\text { First } \\
\text { scan }\end{array}$ & $\begin{array}{c}\text { Second } \\
\text { scan }\end{array}$ & $\begin{array}{c}\text { Mean } \\
\text { value }\end{array}$ \\
\hline $\begin{array}{c}\text { Zpol } \\
(\Omega)\end{array}$ & 238,8 & 235,4 & 237,1 & 256 & 246 & 251 \\
\hline
\end{tabular}

The results indicate that the surface of WE1 (modified with rough sand paper) delivers more current to the nerve tissue and more activation for a fixed input voltage than WE2 (modified with fine sand paper). Consequently, as the total delivered current is reduced, this activation is obtained at a relatively reduced input power.

Our results are consistent with the results of other investigators. ${ }^{5}$ Namely, in the study, the pulse was predefined to retain a near-zero net charge while employing an asymmetry in the current and pulse widths for the cathodic and anodic phases. ${ }^{30}$ By doing so, the $E_{\text {ipp }}$ of both WEs is maintained within a potential range that avoids WE damage and potential tissue injury. In clinical practice, the latter is generally more of a concern than damage to the WE. The relatively large real area of both WEs obtained by mechanical roughening is largely responsible for accommodating a certain amount of charge on the DL prior to initiating the Faradaic reactions. However, WE1 presumably accommodated larger amounts of charge than WE2. The electrode impedance is strongly related to the surface area at the interface between the electrode and the electrolyte.

Roughening the surface of both the WEs significantly decreases the $\left|\mathrm{Z}_{\mathrm{pol}}\right|$ of the WE-electrolyte interface, while significantly increasing the capacitance of the DL. ${ }^{32}$ However, the results show that the $\left|Z_{\text {pol }}\right|$ of the WE1-electrolyte interface decreased more than that of the WE2-electrolyte interface and the capacitance of the DL was reversed. Both WEs presumably produce a uniform charge density over each WE, which permits maximum utilization of the proprietary WE surface. ${ }^{33}$ Table 3 shows that the mean $\left|Z_{\mathrm{pol}}\right|$ of WE1 was lower than that for WE2 $(237.1 \Omega$ vs. $251 \Omega)$, which confirmed our initial presumption. ${ }^{34}$

One weakness of the developed method is the sensitivity of the VT measurements with respect to the distance between the WEs and RE. Fortunately, this weakness could be minimized using the optical system, enabling precise control of this distance.

The results support our hypothesis that the $E_{\text {ipp }}$ of WE1 at the onset of the predefined pulse $(-0.83 \mathrm{~V})$ settles at a slightly more negative value at the end of the pulse, indicating that it changes in a negative direction (refer to the measured VT in Figure 3). Presumably, $E_{\mathrm{mc}}$ slightly breaks the cathodic limit before $E_{\text {ma }}$ reaches the anodic limit of the water electrolysis window because of the asymmetric predefined pulse. Consequently, the functionality of WE1 is cathodically limited. This suggests that $E_{\mathrm{mc}}$ slightly exceeds the safe potential limits of water electrolysis $[-0.65 \mathrm{~V}$ to $+0.85 \mathrm{~V}]$ while the $E_{\mathrm{ma}}$ potential does not. Similarly, the $E_{\mathrm{ipp}}$ of WE2 at the onset of the predefined pulse of $-0.75 \mathrm{~V}$ is also settled at a slightly more negative value at the end of the pulse, indicating that it does change less significantly in a negative direction. The functionality of WE2 is also cathodicaly limited.
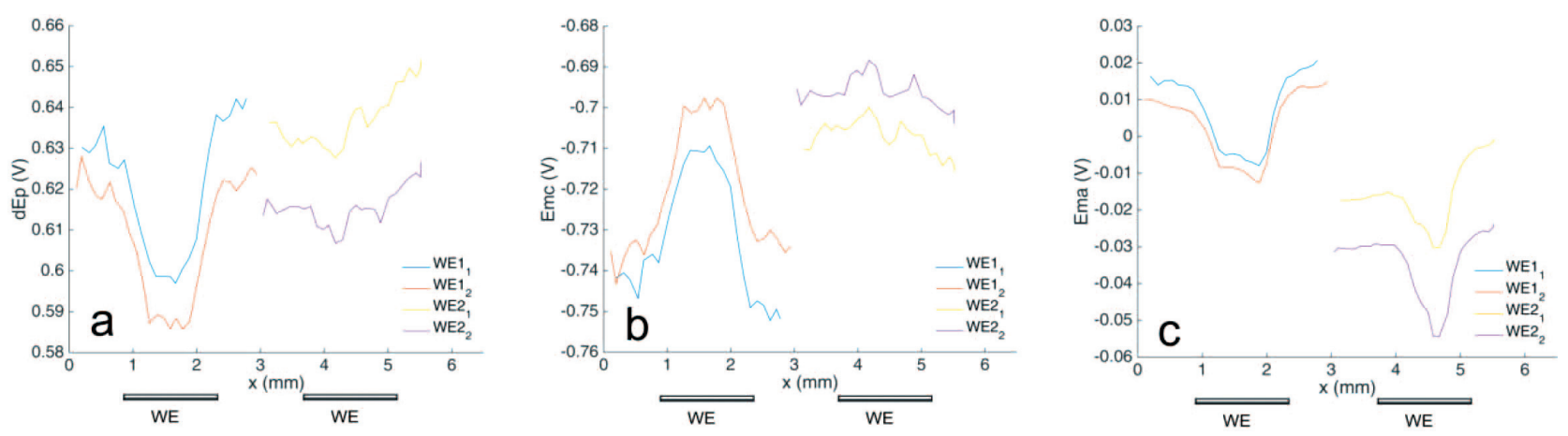

Figure 5: Comparison of $\mathrm{d} E_{\mathrm{p}}$ (left), $E_{\mathrm{mc}}$ (middle), and $E_{\mathrm{ma}}$ (right) with respect to $x$ for WE1 and WE2 
In this regard, C. Newbold et al. ${ }^{22}$ showed that the WE is polarized until another (possibly irreversible) reaction is recruited to maintain the $i_{\mathrm{c}}$ if $i_{\mathrm{c}}$ exceeds the rate at which the counterions for the intended reversible processes are transported to or from the WE. This can happen in vivo, where the $i_{\mathrm{c}}$ distribution can lead to much larger potentials at the edges of the WEs, resulting in possible WE degradation. Considering these results, the described modification of the surface could potentially require less input power, while maintaining the same level of neural activation in vivo.

\section{CONCLUSIONS}

Superficially modified WE1 (using rough sand paper) elicited an increased irregularity and decrease of the current density profile on the surface and consequently in the adjacent nerve tissue in vivo using current pulses. Furthermore, superficially modified WE2 (using fine sand paper) elicited a slightly decreased irregularity and corresponding increase of the current density profile on the surface and consequently in the adjacent nerve tissue in vivo under the same conditions. Thus, the impedance of WE1 is lower than that of WE2. Accordingly, WE1 is more suitable for safe stimulation than WE2.

However, these promising observations warrant extensive in-vivo testing. Future investigations should focus on the involvement of VT measurements and an impedance characterization of the platinum WE in the presence of proteins in vitro and acutely in vivo.

These preliminary findings suggest that the development of such scanning electrochemical methods could potentially provide significant advantages in targeting specific neural populations, allowing optimized therapeutic protocols. This study has contributed to the further development of multi-electrode spiral cuffs for the efficient and safe selective stimulation of autonomous peripheral nerves and the simultaneous selective recording of neural responses.

\section{Acknowledgment}

This work was financed by research grant P3-0171 from the Slovenian Research Agency (ARRS), Ministry of Education, Science and Sport, Ljubljana, Republic of Slovenia.

\section{REFERENCES}

${ }^{1}$ C. R. Butson, C. C. McIntyre, Tissue and electrode capacitance reduce neural activation volumes during deep brain stimulation, Clin. Neurophysiol., 116 (2005), 2490-2500

${ }^{2}$ S. B. Brummer, M. J. Turner, Electrical stimulation of the nervous system: the principle of safe charge injection with noble metal electrodes, Bioelectrochem. Bioenerg., 2 (1975), 13-25

${ }^{3}$ D. R. Merrill, M. Bikson, J. G. R. Jefferys, Electrical stimulation of excitable tissue: design of efficacious and safe protocols, J. Neurosci. Methods, 141 (2005), 171-198
${ }^{4}$ X. F. Wei, W. M. Grill, Analysis of high-perimeter planar electrodes for efficient neural stimulation, Front. Neuroeng., 2 (2009), 15

${ }^{5}$ L. Golestanirad, B. Elahi, A. Molina, J. R. Mosig, C. Pollo, R. Chen, S. J. Graham, Analysis of fractal electrodes for efficient neural stimulation, Front. Neuroeng., 6 (2013), 3

${ }^{6}$ N. Pour Aryan, H. Kaim, A. Rothermel, Electrode Materials: Stateof-the-Art and Experiments, in: Stimulation and Recording Electrodes for Neural Prostheses, Springer International Publishing, Cham, 78 (2015), 45-64

${ }^{7}$ E. N. Warman, W. M. Grill, D. Durand, Modeling the effects of electric fields on nerve fibers: determination of excitation thresholds, IEEE Trans. Biomed. Eng., 39 (1992), 1244-1254

${ }^{8}$ F. Rattay, Analysis of models for extracellular fiber stimulation, IEEE Trans. Biomed. Eng., 36 (1989), 676-682

${ }^{9}$ A. Hung, D. Zhou, R. Greenberg, I. B. Goldberg, J. W. Judy, Pulseclamp technique for characterizing neural-stimulating electrodes, J. Electrochem. Soc., 154 C (2007), 479-486

${ }^{10}$ L. S. Robblee, J. McHardy, W. F. Agnew, L. A. Bullara, Electrical stimulation with Pt electrodes. VII. Dissolution of Pt electrodes during electrical stimulation of the cat cerebral cortex, J. Neurosci. Methods, 9 (1983), 301-308

${ }^{11}$ L. S. Robblee, J. McHardy, J. M. Marston, S. B. Brummer, Electrical stimulation with Pt electrodes. V. The effect of protein on $\mathrm{Pt}$ dissolution, Biomaterials, 1 (1980), 135-139

${ }^{12}$ S. B. Brummer, M. J. Turner, Electrochemical considerations for safe electrical stimulation of the nervous system with platinum electrodes, IEEE Trans. Biomed. Eng., 24 (1977), 59-63

${ }^{13}$ T. L. Rose, L. S. Robblee, Electrical stimulation with Pt electrodes: VIII. Electrochemically safe charge injection limits with $0.2 \mathrm{~ms}$ pulses, IEEE Trans. Biomed. Eng., 37 (1990), 1118-1120

${ }^{14}$ D. B. Hibbert, K. Weitzner, B. Tabor, P. Carter, Mass changes and dissolution of platinum during electrical stimulation in artificial perilymph, Biomaterials, 21 (2000), 2177-2182

${ }^{15}$ D. B. McCreery, W. F. Agnew, T. G. Yuen, L. Bullara, Charge density and charge per phase as cofactors in neural injury induced by electrical stimulation, IEEE Trans. Biomed. Eng., 37 (1990), 996-1001

${ }^{16}$ W. F. Agnew, D. B. McCreery, T. G. H. Yuen, L. A. Bullara, Evolution and resolution of stimulation-induced axonal injury in peripheral nerve, Muscle Nerve, 22 (1999), 1393-1402

${ }^{17}$ P. F. Johnson, L. L. Hench, An in vitro model for evaluating neural stimulating electrodes, J. Biomed. Mater Res. 10 (1976), 907-928

${ }^{18}$ L. A. Geddes, R. Roeder, Criteria for the selection of materials for implanted electrodes, Ann. Biomed. Eng., 31 (2003), 879-890

${ }^{19}$ M. Stevenson, K. Baylor, B. L. Netherton, M. M. Stecker, Electrical stimulation and electrode properties. Part 2: pure metal electrodes, Am. J. Electroneurodiagnostic Technol., 50 (2010), 263-296

${ }^{20}$ E. M. Hudak, J.T. Mortimer, H.B. Martin, Platinum for neural stimulation: voltammetry considerations, J. Neural. Eng., 7 (2010), 026005

${ }^{21}$ M. M. Benmassaoud, M. V. Meller, S. Kuchibhatla, X. F. Wei, Novel fractal planar electrode design for efficient neural stimulation, Proc. 1st IEEE student EMBS, Orlando, FL, USA, (2015), 4 pages

${ }^{22}$ C. Newbold, R. Richardson, R. Millard, C. Huang, D. Milojevic, R. Shepherd, R. Cowan, Changes in biphasic electrode impedance with protein adsorption and cell growth, J. Neural. Eng. 7 (2010), 056011

${ }^{23}$ N. K. Guimard, N. Gomez, C. E. Schmidt, Conducting polymers in biomedical engineering, Prog. Polym. Sci., 32 (2007), 876-921

${ }^{24}$ T. Ragheb, L. A. Geddes, Electrical properties of metallic electrodes, Med. Biol. Eng. Comput., 28 (1990), 182-186

${ }^{25}$ A. Hung, I. B. Goldberg, J, W. Judy, Stimulation electrode materials and electrochemical testing methods, Implantable Neural Prostheses, D. Zhou, E. Greenbaum, 2 (2010), 191-216

${ }^{26}$ P. Pečlin, J. Rozman, Alternative paradigm of selective vagus nerve stimulation tested on an isolated porcine vagus nerve, The Scientific World Journal, 1 (2014), 310283 


\section{MATERIALI IN TEHNOLOGIJE/MATERIALS AND TECHNOLOGY (1967-2017) - 50 LET/50 YEARS}

\section{A. MEHLE et al.: SURFACE CHARACTERIZATION OF PLATINUM STIMULATING ELECTRODES ...}

${ }^{27}$ P. Pečlin, A. Mehle, B. Karpe, J. Rozman, Electrochemical and electrophysiological performance of platinum electrodes within the ninety-nine-electrode stimulating nerve cuff, Artif. Organs, 39 (2015), 886-896

${ }^{28}$ N. de N. Donaldson, P. E. K. Donaldson, When are actively balanced biphasic ('Lilly') stimulating pulses necessary in a neurological prosthesis?: I. Historical background; Pt resting potential; Q studies, Med. Biol. Eng. Comput., 24 (1986), 41-49

${ }^{29}$ N.de N. Donaldson, P. E. K. Donaldson, When are actively balanced biphasic ('Lilly') stimulating pulses necessary in a neurological prosthesis?: II. pH changes; noxious products; electrode corrosion; discussion, Med. Biol. Eng. Comput., 24 (1986), 50-56

${ }^{30}$ S. F. Cogan, Neural stimulation and recording electrodes, Annu. Rev. Biomed. Eng., 10 (2008), 275-309
${ }^{31}$ J.S. Temenoff, A.G. Mikos, Biomaterials: The Intersection of Biology and Materials Science, Pearson/Prentice Hall, Upper Saddle River, NJ, USA, (2008), 235-258

${ }^{32}$ B. Onaral, H. P. Schwan, Linear and nonlinear properties of platinum electrode polarisation. Part 1: frequency dependence at very low frequencies, Med. Biol. Eng. Comput., 20 (1982), 299-306

${ }^{33}$ D. A. Ksienski, A minimum profile uniform current density electrode, IEEE Trans. Biomed. Eng., 39 (1992), 682-692

${ }^{34}$ W. Franks, I. Schenker, P. Schmutz, A. Hierlemann, Impedance characterization and modeling of electrodes for biomedical applications, IEEE Trans. Biomed. Eng., 52 (2005), 1295-1302 